Situs Jurnal : $\underline{\text { http://ejurnal.stiepancasetia.ac.id/index.php/jieb }}$

Jilid 5 Nomor 1 Maret 2019

Hal 088 - 102

\title{
ANALISIS PENILAIAN KESEHATAN KEUANGAN PADA KOPERASI TIRTA LESTARI BANJARBARU
}

\section{Dwinita Anggraini Putri*}

Abstract: This research is to know the analysical of finance healthing-evaluation to Koperasi Tirta Lestari Banjarbaru and to know evaluation analysical result healthing of finance to Koperasi Tirta Lestari Banjarbaru. Research method to use it technique descriptive analysical is that related to with how to descript it, to describe it, to explain it and decompose it data so that easy to be understood. Research result show that evaluation analysical result healthing of finance to Koperasi Tirta Lestari Banjarbaru with capitaling aspect, productive assets quality, management, efisiension, liquiditas, stand aloneness and growing also jatidiri in 2015-2017 to show level of healthing to Koperasi Tirta Lestari Banjarbaru be to category "Enough of Health" with number value obtaining to interval $66,00-80,00$.

\section{Keywords: Koperasi's finance health, Koperasi Tirta Lestari Banjarbaru}

Abstrak: Tujuan dari penelitian ini untuk mengetahui analisis penilaian kesehatan keuangan pada Koperasi Tirta Lestari Banjarbaru dan mengetahui hasil analisis penilaian kesehatan keuangan pada Koperasi Tirta Lestari Banjarbaru. Metode penelitian menggunakan teknik analisis deskriptif adalah analisis yang berkenaan dengan bagaimana mendeskripsikan, menggambarkan, menjabarkan dan menguraikan data agar mudah dipahami. Hasil penelitian menunjukkan bahwa hasil analisis penilaian kesehatan keuangan pada Koperasi Tirta Lestari Banjarbaru dengan aspek permodalan, kualitas aktiva produktif, manajemen, efesiensi, likuiditas, kemandirian dan pertumbuhan serta jatidiri pada tahun 2015-2017 menunjukkan tingkat kesehatan pada Koperasi Tirta Lestari Banjarbaru berada pada kategori "Cukup Sehat" dengan perolehan nilai angka pada interval 66,00 - <80,00.

\section{Kata kunci : Kesehatan Keuangan Koperasi, Koperasi Tirta Lestari Banjarbaru}

\section{Latar Belakang}

Koperasi Tirta Lestari di Banjarbaru yang usahanya adalah mengumpulkan dana dan menyalurkan pinjaman kepada anggota perlu dikelola secara profesional untuk meningkatkan kepercayaan dan memberikan manfaat yang sebesar-besarnya kepada anggota dan masyarakat di sekitarnya. Karena Koperasi Tirta Lestari di Banjarbaru dalam penilaian tingkat kesehatan koperasi belum pernah dilakukan. Selain melihat dari sisi keuangan, penilaian aspek manajemen juga sangat diperlukan agar pengelolaan koperasi dilaksanakan dengan profesional, efektif dan efisien. Manajemen koperasi yang baik, menghasilkan kebijakan yang sesuai dengan tujuan dan mendukung kemajuan koperasi. Maka dari itu, untuk melihat kesehatan koperasi tidak hanya melihat aspek keuangannya saja tetapi juga menilai aspek manajemennya.

Analisis laporan keuangan merupakan suatu proses untuk mengetahui posisi keuangan, hasil operasi dan perkembangan suatu organisasi dengan cara mempelajari hubungan dari datadata atau faktor-faktor keuangan serta kecenderungan yang terdapat dalam suatu laporan keuangan ataupun dalam beberapa laporan keuangan komparatif sehingga dengan melakukan 
suatu analisis terhadap laporan keuangan, informasi dan data keuangan yang diinginkan akan mudah dimengerti serta dapat dijadikan sebagai dasar dalam mengambil keputusan. Kementerian Koperasi dan Usaha Kecil dan Menengah Republik Indonesia Nomor 06 /Per/Dep.6/IV/2016 tentang Pedoman Penilaian Kesehatan Koperasi Simpan Pinjam dan Unit Simpan Pinjam mengatur aspek permodalan, kualitas aset produktif, manajemen, efesiensi, likuiditas, kemandirian dan pertumbuhan serta jatidiri koperasi.

Analisis penilaian kesehatan keuangan koperasi sangat penting dilakukan. Hal ini untuk mengetahui kondisi koperasi ditinjau dari kesehatan keuangannya. Hasil penilaian kesehatan koperasi akan menunjukkan predikat koperasi, yaitu predikat sehat, cukup sehat, kurang sehat, tidak sehat atau sangat tidak sehat. Dengan mengetahui kondisi kesehatan koperasi dapat menjadi bahan pertimbangan untuk merumuskan kebijakan guna pengembangan Koperasi Tirta Lestari di Banjarbaru yang memiliki hasil opini audit tidak menyatakan pendapat, sehingga terwujud pengelolaan KSP yang sehat dan mantap; pengelolaan KSP yang efektif, efisien, dan profesional; dan terciptanya pelayanan prima kepada anggotanya.

Dari latar belakang tersebut maka peneliti tertarik untuk membahas jauh lebih lanjut mengenai kondisi kesehatan keuangan Koperasi Tirta Lestari di Banjarbaru. Judul yang diajukan oleh peneliti adalah "Analisis Penilaian Kesehatan Keuangan Pada Koperasi Tirta Lestari Banjarbaru".

Penelitian ini dibatasi pada masalah kesehatan pada Koperasi Tirta Lestari Banjarbaru tahun 2015-2017 berdasarkan Permen KUKM Nomor 06/Per/Dep.6/IV/2016 tentang Pedoman Penilaian Kesehatan Koperasi.

\section{Kajian Literatur}

Rasio keuangan berdasarkan Peraturan Menteri Negara Koperasi dan Usaha Kecil dan Menengah Republik Indonesia No.06/Per/M.KUKM/IV/2016):

1. Rasio Pemodalan adalah penilaian antara modal sendiri terhadap total asset, rasio modal sendiri tehadap pinjaman berisiko yang diberikan dan rasio kecukupan modal sendiri. Rumus kompenen Rasio Pemodalan, antara lain:

a. Rasio Modal Sendiri terhadap total asset

$$
\frac{\text { Modal Sendiri }}{\text { Total Aset }} \times 100 \%
$$

b. Rasio Modal Sendiri terhadap Pinjaman diberikan yang berisiko

$$
\frac{\text { Modal Sendiri }}{\text { Pinjaman diberikan yang berisiko }} \times 100 \%
$$

c. Rasio Kecukupan Modal Sendiri

\section{Modal Sendiri Tertimbang ATMR $\mathbf{x} 100 \%$}

2. Rasio Kualitas Aktiva Produktif adalah penilaian terhadap aspek kualitas asset atau aktiva produktif berdasarkan pada empat rasio yaitu rasio volume pinjaman pada anggota terhadap volume pinjaman yang diberikan, rasio risiko pinjaman bermasalah terhadap pinjaman yang diberikan, rasio cadangan risiko terhadap risiko pinjaman bermasalah dan 
rasio pinjaman yang berisiko terhadap pinjaman yang diberikan. Rumus komponen Kualitas Aktiva Produktif, antara lain:

a. Rasio Volume Pinjaman pada anggota terhadap volume pinjaman diberikan

$\frac{\text { Volume Pinjaman pada anggota }}{\text { Volume Pinjaman }} \times 100 \%$

b. Rasio Risiko Pinjaman Bermasalah Terhadap Pinjaman yang diberikan

$\frac{\text { Pinjaman bermasalah }}{\text { Pinjaman yang diberikan }} \times 100 \%$

c. Rasio Cadangan Risiko Terhadap Pinjaman Bermasalah

$\frac{\text { Cadangan risiko }}{\text { Pinjaman bermasalah }} \times 100 \%$

Catatan : Cadangan risiko adalah cadangan tujuan risiko + penyisihan penghapusan pinjaman

d. Rasio Pinjaman yang berisiko terhadap pinjaman yang diberikan

$\frac{\text { Pinjaman yang berisiko }}{\text { Pinjaman yang diberikan }}$ x $100 \%$

3. Aspek Manajemen merupakan penilaian aspek manajemen meliputi lima komponen yaitu manajemen umum, kelembagaan, permodalan, manajemen aktiva dan manajemen likuiditas.

4. Rasio Efisiensi adalah : penilaian efisiensi Koperasi Simpan Pinjam / Unit Simpan Pinjam yang akan memperlihatkan seberapa besar koperasi mampu memberikan pelayanan yang efisien kepada anggotanya berdasarkan penggunaan asset yang telah dimilikinya. Rasio Efisiensi terdiri dari : rasio beban operasi anggota terhadap partisipasi bruto, rasio beban usaha terhadap SHU kotor dan rasio efisiensi pelayanan. Rumus komponen Rasio efisiensi, antara lain:

a. Rasio beban operasi anggota terhadap partisipasi bruto

Beban Operasi Anggota

Partisipasi Bruto

Catatan: Beban operasi anggota adalah beban pokok ditambah dengan beban usaha bagi anggota + beban perkoperasian. Untuk Unit Simpan Pinjam (USP) Koperasi, beban perkoperasian di hitung secara proporsional.

b. Rasio beban usaha terhadap Kotor

$\frac{\text { Beban Usaha }}{\text { SHU Kotor }} \times 100 \%$ 
c. Rasio efisiensi pelayanan

$\frac{\text { Biaya Karyawan }}{\text { Volume Pinjaman }}$ x $100 \%$

5. Rasio Likuiditas adalah penilaian kuantitatif terhadap likuiditas koperasi yang dilakukan dengan Rasio Kas dan Bank terhadap kewajiban lancar dan rasio pinjaman yang diberikan terhadap dana yang diterima. Rumus komponen Rasio Likuiditas, antara lain:

a. Rasio Kas

$$
\frac{\text { Kas }+ \text { Bank }}{\text { Kewajiban Lancar }} \times 100 \%
$$

b. Rasio Pinjaman yang diberikan terhadap dana yang diterima

Pinjaman yang diberikan

Dana yang diterima

Catatan : Dana yang diterima adalah total pasiva selain hutang biaya dan SHU belum dibagi.

6. Rasio Kemandirian dan Pertumbuhan adalah penilaian terhadap kemandirian dan pertumbuhan yang didasarkan pada rasio rentabilitas asset, rasio rentabilitas modal sendiri dan rasio kemandirian operasional pelayanan. Rumus komponen Rasio Kemandirian dan Pertumbuhan, antara lain:

a. Rentabilitas asset

$$
\frac{\text { SHU Sebelum Pajak }}{\text { Total Aset }} \times 100 \%
$$

b. Rentabilitas Modal Sendiri

$$
\frac{\text { SHU Bagian Anggota }}{\text { Total Modal Sendiri }} \text { x } 100 \%
$$

c. Kemandirian Operasional Pelayanan

$$
\frac{\text { Pastisipasi Neto }}{\text { Beban Usaha + Beban Perkoperasian }} \times 100 \%
$$

Catatan : Beban usaha adalah beban usaha bagi anggota

7. Rasio Jati Diri Koperasi adalah untuk mengukur keberhasilan koperasi dalam mencapai tujuannya yaitu mempromosikan ekonomi anggota, penilaiannya dengan menggunakan rasio partisipasi bruto dan rasio promosi ekonomi anggota. Rumus komponen Rasio Jati Diri, antara lain:

a. Rasio partisipasi Bruto

$$
\frac{\text { Partisipasi Bruto }}{\text { Partisipasi bruto + Pendapatan }} \times 100 \%
$$


b. Rasio promosi ekonomi anggota (PEA)

$\frac{\text { PEA }}{\text { Simpanan Pokok + Simpanan Wajib }} \times 100 \%$

PEA $=$ MEPPP + SHU Bagian Anggota

Kerangka berpikir dalam penelitian ini dapat digambarkan sebagai berikut untuk memperjelaskan arah tujuan penelitian yang dilakukan:

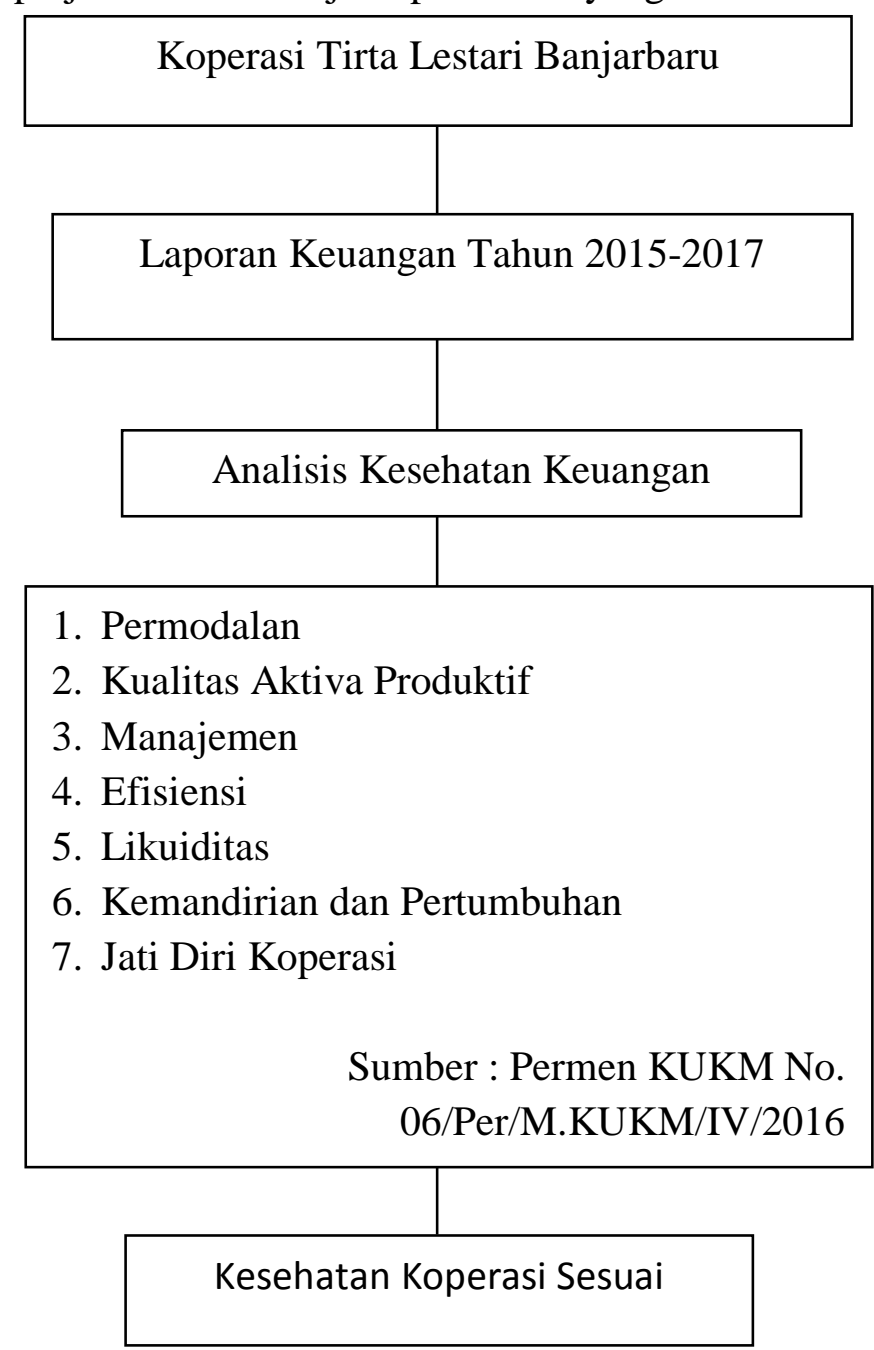

\section{Gambar 1 : Kerangka Berpikir}

\section{Metode Penelitian}

Penelitian ini menggunakan metode analisis deskriptif. Penelitian deskriptif adalah penelitian yang berusaha mendeskripsikan suatu gejala, peristiwa, kejadian yang terjadi saat sekarang. Penelitian deskriptif memusatkan perhatian pada masalah aktual sebagaimana adanya pada saat penelitian berlangsung. Melalui penelitian deskriptif, peneliti berusaha mendeskripsikan peristiwa dan kejadian yang menjadi pusat perhatian tanpa memberikan perlakuan khusus terhadap peristiwa tersebut. 
Jenis data yang digunakan dalam penulisan skripsi ini meliputi (1) Data kuantitatif merupakan data yang biasa dihitung atau diukur. Data ini berbentuk angka. Dalam hal ini data yang digunakan adalah laporan keuangan Koperasi Tirta Lestari Banjarbaru yang berupa neraca dan perhitungan sisa hasil usaha. (2) Data kualitatif merupakan data yang bersifat penjelasan ataupun uraian maupun narasi berdasarkan hasil wawancara. Data ini meliputi gambaran umum Koperasi Tirta Lestari Banjarbaru seperti sejarah berdirinya, struktur organisasi dan lain sebagainya.

Sumber data yang digunakan dalam penulisan skripsi ini yaitu (1) Data Primer, yaitu data penelitian tentang kinerja keuangan, tingkat kesehatan koperasi yang diperoleh melalui dokumen-dokumen laporan keuangan seperti: neraca, laporan perhitungan sisa hasil usaha (SHU). (2) Data Sekunder, yaitu data yang diperoleh melalui pengamatan dan wawancara langsung dengan pengurus Koperasi Tirta Lestari Banjarbaru, serta sumber-sumber lainnya berupa informasi terutama dokumentasi dan laporan pertanggungjawaban pengurus.

Metode penelitian yang digunakan dalam penelitian ini adalah (1) Penelitian Kepustakaan (Library Research), yaitu penelitian yang dilakukan dengan cara mengadakan peninjauan pada berbagai pustaka dengan membaca dan mempelajari buku-buku akuntansi yang berhubungan dengan masalah yang dibahas guna memperoleh kerangka teori sekaligus sebagai alat dalam menganalisis data yang diperoleh. (2) Penelitian lapangan terdiri dari wawancara, dokumentasi dan observasi.

Penilaian analisis laporan keuangan pada Koperasi Tirta Lestari Banjarbaru dalam menilai kinerja kinerja keuangan didasarkan pada Peraturan Kementerian Koperasi dan Usaha Kecil dan Menengah Republik Indonesia Nomor 06 /Per/Dep.6/IV/2016 tentang Pedoman Penilaian Kesehatan Koperasi Simpan Pinjam dan Unit Simpan Pinjam mengatur aspek permodalan, kualitas aset produktif, manajemen, efesiensi, likuiditas, kemandirian dan pertumbuhan serta jatidiri koperasi.

\section{Hasil Penelitian dan Pembahasan}

Hasil analisis penilaian kesehatan keuangan pada Koperasi Tirta Lestari Banjarbaru dapat dilihat pada Tabel 1, dan dijabarkan sebagai berikut:

1. Penilaian Aspek Permodalan Tahun 2015-2017

Berdasarkan analisis yang telah dilakukan, menunjukkan bahwa pada aspek permodalan Koperasi Tirta Lestari Banjarbaru tahun 2015-2017 diperoleh skor yang sama yaitu 10,50. Rerata skor yaitu 10,50 dimana skor maksimalnya sebesar 15. Skor tersebut berada pada rasio berkisar 60-80, sehingga dikategorikan dengan predikat cukup sehat. Skor tersebut diwakili oleh rasio modal sendiri terhadap total asset, rasio modal sendiri terhadap pinjaman beresiko dan rasio kecukupan modal sendiri dengan rincian penilaian sebagai berikut:

a. Rasio Modal Sendiri terhadap Total Assets

Berdasarkan analisis yang telah dilakukan, menunjukkan bahwa pada tahun 2015, rasio yang diperoleh sebesar 95,22\% sehingga mendapat nilai 25 dengan skor 1,50. Tahun 2016 rasio yang diperoleh sebesar $93,71 \%$ sehingga mendapat nilai 25 dengan skor 1,50. Tahun 2017 rasio yang diperoleh sebesar 93,04\% sehingga mendapat nilai 25 dengan skor 1,50. Rasio rerata yang diperoleh sebesar 94,00 dengan skor rata-rata 1,50 dan merupakan skor terendah. Skor maksimal 6,00 diperoleh ketika rasio diperoleh berada dalam rentang $40 \leq X<60$. Dengan demikian, Koperasi Tirta Lestari Banjarbaru harus menyeimbangkan modal sendiri dengan modal pinjaman melalui peningkatakan pinjaman dari luar guna mencapai kualitas dengan nilai maksimal yaitu ketika jumlah modal sendiri terhadap total modal adalah $40 \%-59 \%$. 
Tabel 1. Rekapitulasi Hasil Rasio

\begin{tabular}{|c|c|c|c|c|c|c|c|c|c|c|c|c|}
\hline \multirow[t]{2}{*}{ Nama Rasio } & \multicolumn{4}{|c|}{2015} & \multicolumn{4}{|c|}{2016} & \multicolumn{4}{|c|}{2017} \\
\hline & Hasil & Nilai & Bobot & Skor & Hasil & Nilai & Bobot & $\begin{array}{c}\text { Sko } \\
\text { r }\end{array}$ & Hasil & Nilai & Bobot & Skor \\
\hline \multicolumn{13}{|l|}{ Aspek Permodalan } \\
\hline a. Rasio modal sendiri terhadap total asets & 95,22 & 25 & 6 & 1,5 & $\begin{array}{c}93,7 \\
1\end{array}$ & 25 & 6 & 1,5 & $\begin{array}{c}93,0 \\
4\end{array}$ & 25 & 6 & 1,5 \\
\hline $\begin{array}{l}\text { b. Rasio modal sendiri terhadap pinjaman diberikan } \\
\text { yang beresiko }\end{array}$ & $\begin{array}{c}108,5 \\
1\end{array}$ & 100 & 6 & 6 & $\begin{array}{c}106 \\
90\end{array}$ & 100 & 6 & 6 & $\begin{array}{c}105 \\
57\end{array}$ & 100 & 6 & 6 \\
\hline c. Rasio kecukupan modal sendiri & $\frac{109,5}{4}$ & $\underline{100}$ & $\underline{3}$ & $\underline{3}$ & $\frac{108,}{91}$ & $\underline{100}$ & $\underline{3}$ & $\underline{3}$ & $\frac{107,}{09}$ & $\underline{100}$ & $\underline{3}$ & $\underline{3}$ \\
\hline Jumlah Skor Permodalan & $\begin{array}{c}313,2 \\
7\end{array}$ & 225 & 15 & $\begin{array}{c}10, \\
5\end{array}$ & $\begin{array}{c}309 \\
52\end{array}$ & 225 & 15 & 10,5 & $\begin{array}{c}305 \\
70\end{array}$ & 225 & 15 & $\begin{array}{c}10 \\
5\end{array}$ \\
\hline \multicolumn{13}{|l|}{ Aspek Kualitas Aktiva Produktif } \\
\hline $\begin{array}{l}\text { a. Rasio volume pinjaman pada anggota terhadap } \\
\text { volume pinjaman diberikan }\end{array}$ & 100 & 100 & 10 & 10 & 100 & 100 & 10 & 10 & 100 & 100 & 10 & 10 \\
\hline $\begin{array}{l}\text { b. Rasio resiko pinjaman bermasalah terhadap pinjaman } \\
\text { yang diberikan }\end{array}$ & 10 & 80 & 5 & 4 & $\begin{array}{c}20,1 \\
1\end{array}$ & 40 & 5 & 2 & $\begin{array}{c}25,6 \\
8\end{array}$ & 40 & 5 & 2 \\
\hline $\begin{array}{l}\text { c. Rasio pinjaman yang beresiko terhadap pinjaman } \\
\text { yang diberikan }\end{array}$ & $\underline{100}$ & $\underline{25}$ & $\underline{5}$ & $\frac{1,2}{\underline{5}}$ & $\underline{100}$ & $\underline{25}$ & $\underline{5}$ & $\underline{1,25}$ & $\underline{100}$ & $\underline{25}$ & $\underline{5}$ & $\frac{1,2}{\underline{5}}$ \\
\hline Jumlah Skor KAP & $\begin{array}{c}209,9 \\
6\end{array}$ & 205 & 20 & $\begin{array}{l}15, \\
25\end{array}$ & $\begin{array}{c}220 \\
11\end{array}$ & 165 & 20 & 15,25 & $\begin{array}{c}225 \\
68\end{array}$ & 165 & 20 & $\begin{array}{l}15, \\
25\end{array}$ \\
\hline \multicolumn{13}{|l|}{ Aspek Manajemen } \\
\hline a. $\quad$ Manajemen Umum & - & 9 & $\begin{array}{c}0,2 \\
5\end{array}$ & $\begin{array}{c}2,2 \\
5\end{array}$ & - & 10 & $\begin{array}{c}0,2 \\
5 \\
\end{array}$ & 2,5 & - & 11 & $\begin{array}{c}0,2 \\
5 \\
\end{array}$ & $\begin{array}{c}2,7 \\
5\end{array}$ \\
\hline b. Manajemen Kelembagaan & - & 6 & 0,5 & 3 & - & 6 & 0,5 & 3 & - & 6 & 0,5 & 3 \\
\hline c. Manajemen Permodalan & - & 3 & 0,6 & 1,8 & - & 3 & 0,6 & 1,8 & - & 3 & 0,6 & 1,8 \\
\hline d. $\quad$ Manajemen Aktiva & - & 5 & 0,3 & 1,5 & - & 5 & 0,3 & 1,5 & - & 5 & 0,3 & 1,5 \\
\hline e. Manajemen Likuiditas & - & $\underline{3}$ & $\underline{0,6}$ & $\underline{1,8}$ & - & $\underline{3}$ & $\underline{0,6}$ & $\underline{1,8}$ & - & $\underline{3}$ & $\underline{0,6}$ & $\underline{1,8}$ \\
\hline Jumlah Skor Manajemen & & 26 & $\begin{array}{c}2,2 \\
5\end{array}$ & $\begin{array}{l}\mathbf{1 0 ,} \\
\mathbf{3 5}\end{array}$ & & 27 & $\begin{array}{c}2,2 \\
5\end{array}$ & $\begin{array}{c}10, \\
6\end{array}$ & & 28 & $\begin{array}{c}2,2 \\
5\end{array}$ & $\begin{array}{l}10, \\
85\end{array}$ \\
\hline \multicolumn{13}{|l|}{ Aspek Efisiensi } \\
\hline $\begin{array}{l}\text { a. Rasio beban operasi anggota terhadap partisipasi } \\
\text { anggota }\end{array}$ & $\begin{array}{c}73,8 \\
5\end{array}$ & 100 & 4 & 4 & $\begin{array}{c}70,0 \\
5\end{array}$ & 100 & 4 & 4 & $\begin{array}{c}79,3 \\
1\end{array}$ & 100 & 4 & 4 \\
\hline b. Rasio beban usaha terhadap SHU kotor & $\begin{array}{c}23,4 \\
7 \\
\end{array}$ & 100 & 4 & 4 & 4,13 & 100 & 4 & 4 & 8,83 & 100 & 4 & 4 \\
\hline c. Rasio efisiensi pelayanan & $\underline{1,57}$ & $\underline{100}$ & $\underline{2}$ & $\underline{2}$ & $\underline{1,14}$ & $\underline{100}$ & $\underline{2}$ & $\underline{2}$ & $\underline{2,39}$ & $\underline{100}$ & $\underline{2}$ & $\underline{2}$ \\
\hline Jumlah Skor Efisiensi & $\begin{array}{c}98,8 \\
9\end{array}$ & 300 & 10 & 10 & $\begin{array}{c}75,3 \\
2 \\
\end{array}$ & 300 & 10 & 10 & $\begin{array}{c}90,5 \\
3 \\
\end{array}$ & 300 & 10 & 10 \\
\hline \multicolumn{13}{|l|}{ Aspek Likuiditas } \\
\hline a. Rasio kas dan bank terhadap kewajiban lancar & $\begin{array}{c}695, \\
34 \\
\end{array}$ & 25 & 10 & 2,5 & $\begin{array}{c}447 \\
48 \\
\end{array}$ & 25 & 10 & 2,5 & $\begin{array}{c}195 \\
27 \\
\end{array}$ & 25 & 10 & 2,5 \\
\hline $\begin{array}{l}\text { b. Rasio pinjaman yang diberikan terhadap dana yang } \\
\text { diterima }\end{array}$ & $\frac{92,0}{\underline{1}}$ & $\underline{100}$ & $\underline{5}$ & $\underline{5}$ & $\frac{91,2}{\underline{5}}$ & $\underline{100}$ & $\underline{5}$ & $\underline{5}$ & $\frac{90,2}{\underline{2}}$ & $\underline{100}$ & $\underline{5}$ & $\underline{5}$ \\
\hline Jumlah Skor Likuiditas & $\begin{array}{c}787 \\
35\end{array}$ & 125 & 15 & 7,5 & $\begin{array}{c}538 \\
73\end{array}$ & 125 & 15 & 7,5 & $\begin{array}{c}285 \\
49\end{array}$ & 125 & 15 & 7,5 \\
\hline \multicolumn{13}{|l|}{ Aspek Kemandirian dan Pertumbuhan } \\
\hline a. Rasio rentabilitas aset & 3,30 & 25 & 3 & $\begin{array}{c}0,7 \\
5 \\
\end{array}$ & 3,93 & 25 & 3 & $\begin{array}{c}0,7 \\
5 \\
\end{array}$ & 2,21 & 25 & 3 & $\begin{array}{c}0,7 \\
5 \\
\end{array}$ \\
\hline b. Rasio rentabilitas modal sendiri & 1,73 & 25 & 3 & $\begin{array}{c}0,7 \\
5\end{array}$ & 2,09 & 25 & 3 & $\begin{array}{c}0,7 \\
5 \\
\end{array}$ & 1,18 & 25 & 3 & $\begin{array}{c}0,7 \\
5 \\
\end{array}$ \\
\hline c. Rasio kemandirian operasional pelayanan & $\frac{187,}{\underline{50}}$ & $\underline{100}$ & $\underline{4}$ & $\underline{4}$ & $\frac{193}{13}$ & $\underline{100}$ & $\underline{4}$ & $\underline{4}$ & $\frac{197}{44}$ & $\underline{100}$ & $\underline{4}$ & $\underline{4}$ \\
\hline Jumlah Skor Kemandirian dan Pertumbuhan & $\begin{array}{c}192, \\
53\end{array}$ & 150 & 10 & 5,5 & $\begin{array}{c}199, \\
15 \\
\end{array}$ & 150 & 10 & 5,5 & $\begin{array}{c}200, \\
83\end{array}$ & 150 & 10 & 5,5 \\
\hline \multicolumn{13}{|l|}{ Aspek Jatidiri Koperasi } \\
\hline a. Rasio Partisipasi Bruto & $\begin{array}{c}91,7 \\
9 \\
\end{array}$ & 100 & 7 & 7 & $\begin{array}{c}89,3 \\
8 \\
\end{array}$ & 100 & 7 & 7 & $\begin{array}{c}97,7 \\
4 \\
\end{array}$ & 100 & 7 & 7 \\
\hline b. Rasio Promosi Ekonomi Anggota (PEA) & $\frac{39,4}{5}$ & $\underline{100}$ & $\underline{3}$ & $\underline{3}$ & $\frac{32,7}{2}$ & $\underline{100}$ & $\underline{3}$ & $\underline{3}$ & $\frac{14,5}{0}$ & $\underline{100}$ & $\underline{3}$ & $\underline{3}$ \\
\hline Jumlah Skor Jatidiri Koperasi & $\begin{array}{c}131, \\
24\end{array}$ & 200 & 10 & 10 & $\begin{array}{c}122, \\
10\end{array}$ & 200 & 10 & 10 & $\begin{array}{c}112 \\
24\end{array}$ & 200 & 10 & 10 \\
\hline TOTAL SKOR & $\begin{array}{l}1.73 \\
3,2 \\
\end{array}$ & $\begin{array}{c}1.23 \\
1,0 \\
\end{array}$ & $\begin{array}{c}82, \\
3\end{array}$ & $\begin{array}{c}69, \\
1 \\
\end{array}$ & $\begin{array}{c}1.46 \\
4,9 \\
\end{array}$ & $\begin{array}{c}1.19 \\
2,0 \\
\end{array}$ & $\begin{array}{c}82 \\
3\end{array}$ & $\begin{array}{c}69, \\
4\end{array}$ & $\begin{array}{c}1.22 \\
0,5 \\
\end{array}$ & $\begin{array}{c}1.19 \\
3,0 \\
\end{array}$ & $\begin{array}{c}82, \\
3\end{array}$ & $\begin{array}{c}69, \\
6\end{array}$ \\
\hline KATEGORI & & Cukup & ehat & & & ukup & ehat & & & Cuku & ehat & \\
\hline
\end{tabular}

b. Rasio Modal Sendiri terhadap Pinjaman Berisiko

Berdasarkan analisis data yang telah dilakukan, menunjukkan bahwa pada tahun 2015, rasio diperoleh sebesar $108,51 \%$ sehingga mendapat nilai 100 dengan skor 6,00. Tahun 
2016 rasio diperoleh sebesar 106,90\% sehingga mendapat nilai 100 dengan skor 6,00. Tahun 2017 rasio diperoleh sebesar 105,57\% sehingga mendapat nilai 100 dengan skor 6,00. Rasio rerata yang diperoleh sebesar $106,99 \%$ dengan skor rata-rata 6,00 dan merupakan skor maksimal. Hal ini berarti modal sendiri Koperasi Tirta Lestari Banjarbaru memiliki kualitas yang sangat baik dalam menjamin pinjaman diberikan yang berisiko pada tahun 2015-2017. Dengan demikian, diharapkan Koperasi Tirta Lestari Banjarbaru dapat mempertahankan kondisi ini dan memperkecil jumlah pinjaman diberikan yang berisiko untuk tahun berikutnya.

\section{c. Rasio Kecukupan Modal}

Berdasarkan analisis yang telah dilakukan, menunjukkan bahwa pada tahun 2015, rasio diperoleh sebesar 109,54\% sehingga mendapat nilai 100 dengan skor 3,00. Tahun 2016 rasio diperoleh sebesar 108,51\% sehingga mendapat nilai 100 dengan skor 3. Tahun 2017 rasio diperoleh sebesar 107,09\% sehingga mendapat nilai 100 dengan skor 3,00. Rasio rata-rata yang diperoleh sebesar 108,51\% dengan skor rerata yang diperoleh yaitu 3,00 dan merupakan skor maksimal. Hal ini berarti modal tertimbang Koperasi Tirta Lestari Banjarbaru memiliki kualitas yang sangat baik dalam mendukung adanya Aktiva Tertimbang Menurut Risiko (ATMR) yang dimiliki pada tahun 2015-2017. Hendaknya Koperasi Tirta Lestari Banjarbaru dapat mempertahankan kondisi ini.

2. Penilaian Aspek Kualitas Aktiva Produktif Tahun 2015-2017

Berdasarkan analisis yang telah dilakukan, menunjukkan bahwa pada aspek kualitas aktiva produktif Koperasi Tirta Lestari Banjarbaru tahun 2015 diperoleh skor 15,25; tahun 2016 dan 2017 diperoleh sama yaitu sebesar 13,25. Rerata skor diperoleh sebesar 13,29 dimana skor maksimalnya adalah 25 . Skor tersebut berada pada rasio berkisar 40-60, sehingga dikategorikan dengan predikat kurang sehat. Hal ini berarti aktiva yang dimiliki belum mencapai tingkat penghasilan yang diharapkan. Skor tersebut diwakili oleh rasio volume pinjaman pada anggota terhadap volume pinjaman diberikan, rasio risiko pinjaman bermasalah terhadap pinjaman yang diberikan, rasio cadangan risiko terhadap pinjaman bermasalah dan rasio pinjaman yang berisiko terhadap pinjaman yang diberikan dengan rincian penilaian sebagai berikut:

a. Rasio Volume Pinjaman pada Anggota terhadap Volume Pinjaman Diberikan

Berdasarkan analisis yang telah dilakukan, menunjukkan bahwa rasio volume pinjaman pada anggota terhadap volume pinjaman diberikan selama tahun 2015-2017 memperoleh hasil. Pada tahun 2015, 2016 dan 2017 rasio diperoleh sebesar 100\% sehingga mendapat nilai 100 dengan skor 10,00. Rasio rata-rata yang diperoleh sebesar 100\% dengan skor 10,00 dan merupakan skor maksimal. Hal ini berarti bahwa Koperasi Tirta Lestari Banjarbaru dalam aktivitas simpan pinjam kepada anggota pada tahun 2015-2017 dapat dikatakan tinggi. Hendaknya Koperasi Tirta Lestari Banjarbaru mempertahankan kondisi ini dan lebih ditingkatkan lagi untuk tahun berikutnya.

b. Rasio Risiko Pinjaman Bermasalah terhadap Pinjaman yang Diberikan

Berdasarkan pada hasil dari analisis yang telah dilakukan, menunjukkan bahwa pada tahun 2015, rasio yang diperoleh sebesar 9,96\% sehingga mendapat nilai 80 dengan skor 4,00. Tahun 2016 rasio diperoleh sebesar 20,11\% sehingga mendapat nilai 40 dengan skor 2,00. Tahun 2017 rasio diperoleh sebesar 25,68\% sehingga mendapat nilai 40 dengan skor 2,00. Rasio rerata yang diperoleh sebesar 18,58\% dengan skor rerata yaitu 2,67; padahal di dalam pedoman penskoran nilai maksimal yang dapat dicapai yaitu 5,00. Skor 
maksimal 5,00 diperoleh ketika rasio yang dihasilkan $=0$. Semakin rendah rasio yang dihasilkan, maka semakin rendah pula risiko pinjaman bermasalah yang terjadi. Hal ini berarti Koperasi Tirta Lestari Banjarbaru memiliki tingkat risiko pinjaman bermasalah yang rendah pada tahun 2015. Namun di tahun 2016 dan 2017 tingkat risiko pinjaman bermasalah pada Koperasi Tirta Lestari Banjarbaru dapat dikatakan cukup tinggi. Dengan demikian perlu adanya peraturan yang lebih tegas dan persyaratan yang lebih jelas ketika nasabah mengajukan pinjaman harus disesuaikan dengan agunan yang memadai. Hal ini diperlukan untuk meminimalisir risiko kerugian.

c. Rasio Cadangan Risiko terhadap Pinjaman Bermasalah

Berdasarkan hasil analisis yang telah dilakukan, Koperasi Tirta Lestari Banjarbaru belum memiliki cadangan risiko pada tahun 2015-2017 sehingga diperoleh rasio 0\% dengan nilai 0. Dengan rasio 0\% berarti Koperasi Tirta Lestari Banjarbaru tidak memiliki tingkat cadangan risiko untuk penghapusan pinjaman bermasalah yang ada pada tahun 20152017. Hendaknya Koperasi Tirta Lestari Banjarbaru membentuk dana alokasi cadangan risiko karena hal ini sangat penting untuk menutup risiko apabila terjadi pinjaman macet atau tidak tertagih.

d. Rasio Pinjaman yang berisiko terhadap Pinjaman yang Diberikan

Berdasarkan hasil analisis yang telah dilakukan, menunjukkan bahwa rasio selama tahun 2015-2017 mendapat rasio rata-rata yaitu 100\% dengan skor rata-rata sebesar 1,25. Pada tahun 2015, 2016 dan 2017 rasio yang dihasilkan sebesar 100\% sehingga memperoleh skor 1,25 . Semakin rendah rasio, maka semakin rendah risiko pinjaman bermasalah yang terjadi. Dengan rasio yang dihasilkan berarti Koperasi Tirta Lestari Banjarbaru memiliki risiko pinjaman bermasalah yang tinggi pada tahun 2015-2017. Dengan demikian Koperasi Tirta Lestari Banjarbaru diharapkan mampu memperkecil pinjaman beresiko melalui kebijakan pinjaman kepada nasabah dengan agunan atau jaminan yang memadai dan dapat diandalkan atas pinjaman yang diberikan tersebut.

\section{Penilaian Aspek Manajemen Tahun 2015-2017}

Berdasarkan hasil analisis yang telah dilakukan, menunjukkan bahwa skor rata-rata yang diperoleh pada aspek manajemen umum yaitu 2,5; skor rata-rata pada aspek manajemen kelembagaan yaitu 3,00; skor rata-rata aspek manajemen permodalan yaitu 1,80; skor ratarata aspek manajemen aktiva yaitu 1,50 dan skor rata-rata aspek manajemen likuiditas 1,80. Rerata skor diperoleh sebesar 10,60 dimana skor maksimalnya adalah 15. Skor tersebut berada pada rasio berkisar 60-80, sehingga dikategorikan dengan predikat cukup sehat.

Berdasarkan perolehan skor tersebut menujukkan bahwa dari aspek manajemen Koperasi Tirta Lestari Banjarbaru telah menjalankan manajemen dengan cukup baik pada tahun 20152017, hanya saja masih perlu meningkatkan pengelolaan manajemen permodalan, manajemen aktiva dan manajemen likuiditas secara efektif dan efisien.

Pengelolaan manajemen permodalan Koperasi Tirta Lestari Banjarbaru diperlukan pembetukan penyisihan cadangan dengan nilai sama atau lebih besar dari seperempat SHU tahun berjalan. Cadangan tersebut berguna untuk pemupukan modal dan pengembangan usaha serta cadangan yang dimaksudkan untuk menutup risiko apabila terjadi pinjaman macet atau tidak tertagih.

Pengelolaan manajemen aktiva perlu meningkatkan pinjaman dengan kolektibilitas lancar dan memiliki kebijakan cadangan penghapusan cadangan pinjaman bermasalah yang 
jumlahnya sama dengan jumlah pinjaman macet tahunan serta pinjaman macet yang terjadi di Koperasi Tirta Lestari Banjarbaru harus dapat tertagih.

Pengelolaan manajemen likuiditas Koperasi Tirta Lestari Banjarbaru perlu memiliki kebijakan tertulis mengenai pengendalian likuiditas serta memiliki kerjasama pendanaan dari lembaga keuangan lainnya untuk menjaga likuiditas Koperasi Tirta Lestari Banjarbaru.

\section{Penilaian Aspek Efisiensi Tahun 2015-2017}

Berdasarkan analisis yang telah dilakukan, menunjukkan bahwa pada aspek efisiensi Koperasi Tirta Lestari di Banjarbaru tahun 2015-2017 diperoleh skor yang sama yaitu 10,00. Rerata skor diperoleh sebesar 10,00 dan merupakan skor maksimal. Hal ini berarti bahwa dalam perihal efisiensi, Koperasi Tirta Lestari di Banjarbaru tergolong sangat baik, yang berarti Koperasi Tirta Lestari di Banjarbaru mampu memberikan pelayanan kepada anggota dengan penggunaan asset dan biaya seefisien mungkin. Dengan skor tersebut dapat dikatakan bahwa aspek efisiensi Koperasi Tirta Lestari di Banjarbaru dikategorikan sehat. Skor tersebut diwakili oleh rasio beban operasi anggota terhadap partisipasi bruto, rasio beban usaha terhadap SHU kotor dan rasio efisiensi pelayanan dengan rincian penilaian sebagai berikut:

a. Rasio Beban Operasi Anggota terhadap Partisipasi Bruto

Berdasarkan analisis yang telah dilakukan, menunjukkan bahwa pada tahun 2015, rasio diperoleh sebesar 73,85\% sehingga mendapat nilai 100 dengan skor 4,00. Tahun 2016 rasio diperoleh sebesar $70,85 \%$ sehingga mendapat nilai 100 dengan skor 4 . Tahun 2017 rasio diperoleh sebesar 79,31\% sehingga mendapat nilai 100 dengan skor 4,00. Rasio rata-rata yang diperoleh sebesar 74,67\% dengan skor 4,00 dan merupakan skor maksimal. Hal ini berarti bahwa Koperasi Tirta Lestari di Banjarbaru telah memberikan efisiensi pelayanan kepada para anggotanya dari penggunaan assets yang dimiliki. Partisipasi bruto yang tinggi menunjukkan bahwa kontribusi anggota terhadap koperasi juga tinggi dan meningkatkan perolehan SHU. Diharapkan Koperasi Tirta Lestari di Banjarbaru mempertahankan atau bahkan meningkatkannya untuk tahun berikutnya.

b. Rasio Beban Usaha terhadap SHU Kotor

Berdasarkan analisis yang telah dilakukan, menunjukkan bahwa pada tahun 2015, rasio diperoleh sebesar 23,47\% sehingga mendapat nilai 100 dengan skor 4,00. Tahun 2016 rasio diperoleh sebesar 4,13\% sehingga mendapat nilai 100 dengan skor 4,00. Tahun 2017 rasio diperoleh sebesar 8,83\% sehingga mendapat nilai 100 dengan skor 4,00. Rasio beban usaha terhadap SHU kotor tahun 2015-2017 memperoleh rasio rata-rata $12,14 \%$ dengan rerata skor diperoleh sebesar 04,00 dan merupakan skor maksimal. Semakin rendah rasio yang dihasilkan, maka semakin tinggi tingkat perolehan SHU. Hal ini berarti Koperasi Tirta Lestari di Banjarbaru berhasil melaksanakan kegiatan simpan pinjam yang efisien dengan beban usaha yang rendah dapat menghasilkan SHU yang tinggi.

c. Rasio Efisiensi Pelayanan

Berdasarkan analisis yang telah dilakukan, menunjukkan bahwa pada tahun 2015, rasio diperoleh sebesar 1,57\% sehingga mendapat nilai 100 dengan skor 2,00. Tahun 2016 rasio diperoleh sebesar 1,14\% sehingga mendapat nilai 100 dengan skor 2 . Tahun 2017 rasio diperoleh sebesar 2,39\% sehingga mendapat nilai 100 dengan skor 2,00.

Rasio efisiensi pelayanan Koperasi Tirta Lestari di Banjarbaru selama tahun 2015-2017 memperoleh hasil rasio rata-rata 1,70\% dengan rerata skor yaitu 2 dan merupakan skor 
maksimal. Semakin rendah rasio yang dihasilkan, maka semakin tinggi skor yang diperoleh. Hal ini berarti bahwa Koperasi Tirta Lestari di Banjarbaru tergolong sangat baik dalam efisiensi pelayanan. Karyawan Koperasi Tirta Lestari di Banjarbaru harus mempertahankan efisiensi pelayanannya kepada anggota agar perolehan SHU dapat maksimal.

\section{Penilaian Aspek Likuiditas Tahun 2015-2017}

Berdasarkan analisis yang telah dilakukan, menunjukkan bahwa pada aspek likuiditas Koperasi Tirta Lestari di Banjarbaru tahun 2015-2017 diperoleh skor yang sama yaitu 7,50. Rerata skor diperoleh sebesar 7,50 dimana skor maksimalnya adalah 15. Skor tersebut berada pada rasio berkisar 40-60, sehingga aspek likuiditas Koperasi Tirta Lestari di Banjarbaru tahun 2015-2017 dikategorikan dengan predikat kurang sehat. Skor yang didapat dalam penilaian aspek likuiditas tersebut diwakili oleh rasio kas dan rasio pinjaman yang diberikan terhadap dana yang diterima dengan rincian penilaian sebagai berikut:

a. Rasio Kas

Berdasarkan analisis yang telah dilakukan, menunjukkan bahwa rasio pada tahun 2015, rasio diperoleh sebesar $695,34 \%$ sehingga mendapat nilai 25 dengan skor 0,25 . Tahun 2016 rasio diperoleh sebesar 447,48\% sehingga mendapat nilai 25 dengan skor 0,25. Tahun 2017 rasio diperoleh sebesar 195,27\% sehingga mendapat nilai 25 dengan skor 0,25. Rasio kas Koperasi Tirta Lestari di Banjarbaru selama tahun 2015-2017 memperoleh hasil rasio rata-rata 446,03\% dengan rerata skor yang diperoleh yaitu 2,5; dan merupakan skor terendah, padahal dalam peraturan penskoran, skor maksimal yang ada sebesar 10. Skor maksimal diperoleh ketika rasio kas berada pada 10-15\%. Hal ini berarti bahwa rasio kas masih buruk. Pada Koperasi Tirta Lestari di Banjarbaru perbandingan antara bank dan kas dengan kewajiban lancar sangatlah tidak seimbang. Dengan demikian dapat dikatakan bahwa terdapat banyak dana yang menganggur sehingga kondisi Koperasi Tirta Lestari di Banjarbaru ada pada over likuid. Koperasi Tirta Lestari di Banjarbaru sebaiknya menyeimbangkan kas dan bank dengan kewajiban lancarnya. Nilai kas dan bank dapat diperkecil dengan cara menyalurkan dana tersebut ke nasabah dalam bentuk pinjaman, sedangkan kewajiban lancar dapat ditingkatkan dengan cara menarik nasabah untuk menabung di Koperasi Tirta Lestari di Banjarbaru.

b. Rasio Pinjaman yang Diberikan terhadap Dana yang Diterima

Berdasarkan analisis yang telah dilakukan, menunjukkan bahwa pada tahun 2015, rasio diperoleh sebesar 92,01\% sehingga mendapat nilai 100 dengan skor 5,00. Tahun 2016 rasio diperoleh sebesar 91,25\% sehingga mendapat nilai 100 dengan skor 5,00. Tahun 2017 rasio diperoleh sebesar 90,22\% sehingga mendapat nilai 100 dengan skor 5,00. Rasio rata-rata selama tahun 2015-2017 memperoleh hasil sebesar 91,16\% dengan skor rerata 5,00 dan merupakan skor maksimal. Semakin tinggi rasio yang dihasilkan, maka semakin rendah tingkat pinjaman bermasalahnya. Hal ini berarti Koperasi Tirta Lestari di Banjarbaru tidak mengalami risiko pinjaman bermasalah dalam prosentase yang besar. Hendaknya Koperasi Tirta Lestari di Banjarbaru dapat mempertahankan atau bahkan meningkatkan rasio untuk tahun berikutnya.

\section{Aspek Kemandirian dan Pertumbuhan Tahun 2015-2017}

Berdasarkan analisis yang telah dilakukan, menunjukkan bahwa pada aspek kemandirian dan pertumbuhan Koperasi Tirta Lestari di Banjarbaru tahun 2015-2017 diperoleh skor yang sama yaitu 5,50. Rerata skor diperoleh sebesar 5,50 dimana skor maksimalnya adalah 10. 
Skor tersebut berada pada rasio berkisar 40-60, sehingga aspek kemandirian dan pertumbuhan Koperasi Tirta Lestari di Banjarbaru tahun 2015-2017 dikategorikan dengan predikat kurang sehat. Skor yang diperoleh dalam penilaian aspek kemandirian dan pertumbuhan tersebut diwakili oleh rasio rentabilitas, rasio ekuitas dan kemandirian operasional dengan rincian penilaian sebagai berikut:

a. Rasio Rentabilitas Assets

Berdasarkan analisis yang telah dilakukan, menunjukkan bahwa pada tahun 2015, rasio yang diperoleh sebesar 3,30\% sehingga mendapatkan nilai 25 dengan skor 0,75 . Pada tahun 2016 rasio yang diperoleh sebesar 3,39\% sehingga mendapatkan nilai 25 dengan skor 0,75 . Tahun 2017 rasio diperoleh sebesar 2,21\% sehingga mendapat nilai 25 dengan skor 0,75. Rasio selama tahun 2015-2017 memperoleh hasil rasio rata-rata 2,97\% dengan rerata skor yang diperoleh yaitu 0,75 dan merupakan skor terendah. Skor maksimal yang dapat diperoleh yaitu 3,00; dengan rasio $>10 \%$ berdasarkan peraturan penskoran. Semakin tinggi rasio yang diperoleh, maka semakin tinggi tingkat rentabilitasnya. Hal ini berarti rentabilitas asset Koperasi Tirta Lestari di Banjarbaru dalam kondisi yang buruk. Hendaknya Koperasi Tirta Lestari di Banjarbaru mampu meningkatkan perolehan SHU sebelum pajak dengan memaksimalkan pendapatan melalui partisipasi anggota dalam kegiatan simpan pinjam.

\section{b. Rasio Rentabilitas Modal Sendiri}

Berdasarkan analisis yang telah dilakukan, menunjukkan bahwa pada tahun 2015, rasio diperoleh sebesar 1,73 sehingga mendapat nilai 25 dengan skor 0,75 . Tahun 2016 rasio diperoleh sebesar 2,09\% sehingga mendapat nilai 25 dengan skor 0,75 . Tahun 2017 rasio diperoleh sebesar $1,18 \%$ sehingga mendapat nilai 25 dengan skor 0,75 . Secara rerata, rasio yang diperoleh sebesar $1,67 \%$ dengan skor 0,75 dan merupakan skor terendah berdasarkan pedoman penskoran. Hal ini berarti rentabilitas modal sendiri Koperasi Tirta Lestari di Banjarbaru dalam kondisi yang buruk. Hendaknya Koperasi Tirta Lestari di Banjarbaru mampu meningkatkan perolehan SHU bagian anggota dengan memaksimalkan partisipasi simpanan pokok, simpanan wajib dan transaksi pelayanan KSP oleh anggota.

c. Rasio Kemandirian dan Operasional Pelayanan

Berdasarkan analisis yang telah dilakukan, menunjukkan bahwa pada tahun 2015, rasio diperoleh sebesar 187,50\% sehingga mendapat nilai 100 dengan skor 4,00. Tahun 2016 rasio diperoleh sebesar 193,13\% sehingga mendapat nilai 100 dengan skor 4 . Tahun 2017 rasio diperoleh sebesar 197,44\% sehingga mendapat nilai 100 dengan skor 4,00. Rasio selama tahun 2015-2017 memperoleh hasil rasio rata-rata 192,69\% dengan rerata skor yang diperoleh adalah 4,00 dan merupakan skor maksimal. Beban usaha dan beban perkoperasian yang dikeluarkan sangat efisien dibandingkan dengan partisipasi neto yang tinggi sehingga diperoleh kualitas yang maksimal. Hal ini berarti bahwa dalam perihal rasio kemandirian dan operasional pelayanan tergolong sangat baik. Koperasi Tirta Lestari di Banjarbaru diharapkan mampu mempertahankan dan bahkan meningkatkan pelayanannya di tahun berikutnya.

\section{Penilaian Aspek Jatidiri Tahun 2015-2017}

Berdasarkan analisis yang telah dilakukan, menunjukkan bahwa pada aspek jatidiri Koperasi Tirta Lestari di Banjarbaru tahun 2015-2017 diperoleh skor yang sama yaitu 10,00. Rerata skor diperoleh sebesar 10,00 dan merupakan skor maksimal. Hal ini berarti bahwa Koperasi 
Tirta Lestari di Banjarbaru tergolong sangat baik dan berhasil dalam mencapai tujuannya yaitu mempromosikan ekonomi anggota. Dengan rasio tersebut dapat dikatakan bahwa aspek jatidiri Koperasi Tirta Lestari di Banjarbaru dikategorikan sehat. Skor tersebut diwakili oleh rasio partisipasi bruto dan rasio promosi ekonomi anggota dengan rincian penilaian sebagai berikut:

a. Rasio Partisiasi Bruto

Berdasarkan analisis yang telah dilakukan, menunjukkan bahwa pada tahun 2015, rasio diperoleh sebesar 91,79\% sehingga mendapat nilai 100 dengan skor 7,00. Tahun 2016 rasio diperoleh sebesar $89,38 \%$ sehingga mendapat nilai 100 dengan skor 7,00. Tahun 2017 rasio diperoleh sebesar 97,74\% sehingga mendapat nilai 100 dengan skor 7,00. Rasio selama tahun 2015-2017 memperoleh hasil rasio rata-rata 92,97\% dengan skor ratarata yang diperoleh yaitu 7,00 dan merupakan skor maksimal. Hal ini berarti bahwa rasio partisipasi bruto pada Koperasi Tirta Lestari di Banjarbaru memiliki kondisi sangat baik. Diharapkan Koperasi Tirta Lestari di Banjarbaru dapat mempertahankan kondisi ini.

b. Rasio Promosi Ekonomi Anggota

Berdasarkan analisis yang telah dilakukan, menunjukkan bahwa pada tahun 2015, rasio diperoleh sebesar 39,45\% sehingga mendapat nilai 100 dengan skor 3,00. Tahun 2016 rasio diperoleh sebesar 32,72\% sehingga mendapat nilai 100 dengan skor 3,00. Tahun 2017 rasio diperoleh sebesar 14,50\% sehingga mendapat nilai 100 dengan skor 3,00. Rasio selama tahun 2015-2017 memperoleh hasil rasio rata-rata 28,89\% dengan rerata skor yang diperoleh adalah 3,00 dan merupakan skor maksimal. Hal ini berarti Koperasi Tirta Lestari di Banjarbaru telah memberikan manfaat efisiensi partisipasi dan manfaat efisiensi biaya koperasi melalui simpanan pokok dan simpanan wajibnya.

\section{Kesimpulan}

Hasil analisis penilaian kesehatan keuangan pada Koperasi Tirta Lestari Banjarbaru dengan aspek permodalan, kualitas aktiva produktif, manajemen, efesiensi, likuiditas, kemandirian dan pertumbuhan serta jatidiri pada tahun 2015-2017 menunjukkan tingkat kesehatan pada Koperasi Tirta Lestari Banjarbaru berada pada kategori "Cukup Sehat" dengan perolehan nilai angka pada interval $66,00-<80,00$.

Saran yang dapat disampaikan setelah mengetahui hasi dari penelitian ini adalah sebagai berikut:

1. Mengingat kualitas aspek permodaan Koperasi Tirta Lestari Banjarbaru tahun 2015-2017 berada dalam kondisi cukup sehat, maka hendaknya pihak Koperasi Tirta Lestari Banjarbaru dapat menyeimbangkan modal sendiri terhadap modal pinjaman melalui peningkatakan pinjaman dari luar guna mencapai nilai maksimal yaitu ketika jumlah modal sendiri terhadap total modal adalah $40 \%-59 \%$.

2. Mengingat kualitas aktiva produktif Koperasi Tirta Lestari Banjarbaru periode 2015-2017 berada dalam kategori kurang sehat, maka sebaiknya pengelola Koperasi Tirta Lestari Banjarbaru perlu membuat peraturan yang lebih tegas dan persyaratan yang lebih ketat ketika nasabah mengajukan pinjaman harus disesuaikan dengan agunan yang memadai. Hal ini diperlukan untuk memperkecil pinjaman beresiko dan meminimalisir risiko kerugian.

3. Mengingat kualitas manajemen Koperasi Tirta Lestari Banjarbaru periode 2015-2017 berada dalam kategori cukup sehat, maka sebaiknya pihak pengurus Koperasi Tirta Lestari Banjarbaru senantiasa dapat mempertahankan kelembagaan yang memiliki kualitas baik dan meningkatkan kualitas manajemen umum yang sudah cukup baik serta perlu melakukan perbaikan-perbaikan dan meningkatkan pengelolaan manajemen permodalan, manajemen 
aktiva dan manajemen likuiditas secara efektif dan efisien agar didapatkan kualitas yang maksimal. Pengelolaan manajemen permodalan Koperasi Tirta Lestari Banjarbaru diperlukan pembetukan penyisihan cadangan yang dimaksudkan untuk menutup risiko apabila terjadi pinjaman macet atau tidak tertagih. Pengelolaan manajemen aktiva perlu meningkatkan pinjaman dengan kolektibilitas lancar dan perihal pinjaman macet yang terjadi di Koperasi Tirta Lestari Banjarbaru harus dapat tertagih. Pengelolaan manajemen likuiditas Koperasi Tirta Lestari Banjarbaru perlu memiliki kebijakan tertulis mengenai pengendalian likuiditas serta memiliki kerjasama pendanaan dari lembaga keuangan lainnya untuk menjaga likuiditas Koperasi Tirta Lestari Banjarbaru.

4. Mengingat kualitas efisiensi Koperasi Tirta Lestari Banjarbaru periode 2015-2017 berada pada kategori sehat, maka pengelola Koperasi Tirta Lestari Banjarbaru diharapkan dapat mempertahankan kualitas efisiensi yang sudah baik.

5. Mengingat kualitas likuiditas yang dimiliki periode 2015-2017 berada pada kategori kurang sehat, diharapkan pengelola Koperasi Tirta Lestari Banjarbaru dapat melakukan perbaikan dalam pengelolaan rasio kas yang masih buruk. Nilai kas dan bank dapat diperkecil dengan cara menyalurkan dana tersebut ke nasabah dalam bentuk pinjaman, sedangkan kewajiban lancar dapat ditingkatkan dengan cara menarik nasabah untuk menabung di Koperasi Tirta Lestari Banjarbaru.

6. Mengingat kualitas kemandirian dan pertumbuhan yang dimiliki Koperasi Tirta Lestari Banjarbaru periode 2015-2017 berada pada kategori kurang sehat, pengelola Koperasi Tirta Lestari Banjarbaru diharapkan mampu mempertahankan kemandirian operasioal pelayanan yang sudah baik dan maksimal dan melakukan perbaikan pada rentabilitas asset dan modal sendiri. Rentabilitas asset Koperasi Tirta Lestari Banjarbaru dalam kondisi yang buruk. Hendaknya Koperasi Tirta Lestari Banjarbaru mampu meningkatkan perolehan SHU sebelum pajak dengan memaksimalkan pendapatan melalui partisipasi anggota dalam kegiatan simpan pinjam. Selain itu, untuk perbaikan rentabilitas modal sendiri yang buruk, hendaknya Koperasi Tirta Lestari Banjarbaru mampu meningkatkan perolehan SHU bagian anggota dengan memaksimalkan partisipasi simpanan pokok, simpanan wajib dan transaksi pelayanan oleh anggota.

7. Mengingat kualitas jatidiri yang dimiliki pada periode 2015-2017 berada pada kategori sehat, maka pengelola Koperasi Tirta Lestari Banjarbaru diharapkan mampu mempertahankan kondisi ini.

8. Mengingat tingkat kesehatan Koperasi Tirta Lestari Banjarbaru selama 3 tahun hanya berada dalam kriteria cukup sehat dan belum mencapai kategori sehat, yang disebabkan oleh rendahnya aspek kualitas aktiva produktif, likuiditas, dan aspek kemandirian dan pertumbuhan maka sangat diperlukan perbaikan agar dapat memperoleh kualitas yang baik. Selain itu, perlu ditingkatkan lagi kualitas pada aspek permodalan dan aspek manajemen yang sudah cukup baik namun belum mencapai kualitas yang maksimal. Aspek-aspek yang sudah baik dan dikategorikan sehat seperti aspek efisiensi dan aspek jatidiri koperasi agar pihak koperasi sebaiknya dapat mempertahankan kondisi ini.

\section{DAFTAR PUSTAKA}

Baswir. Revrisond, 2015, Koperasi Indonesia Edisi Pertama. Yogyakarta: BPFE.

Chaniago, Drs. Arifinal dan Christian Tuweula dkk. 2014. Ekonomi 2. Bandung: Angkasa Farah Margaretha, 2013, Manajemen Keuangan Untuk Non Keuangan. Jakarta: Erlangga.

Gunawan Adisaputro dan Marwan Asri. 2013. Anggaran Perusahaan Edisi 2. Yogyakarta: BPFE. 
Hanafi, Mamduh M. dan Abdul Halim. 2014. Analisis Laporan Keuangan. Yogyakarta: Unit Penerbit Dan Percetakan.

Indriyo Gitosudarmo \& M. Najmudin. 2013. Anggaran Perusahaan. Yogyakarta: BPFE.

Irham Fahmi. 2013. Analisis Kinerja Keuangan. Bandung: Alfabeta.

Jumingan. 2015. Analisis Laporan Keuangan. Jakarta: PT Bumi Aksara.

Munawir, S. 2014. Analisa Laporan Keuangan. Yogyakarta: Liberty Yogyakarta.

Peraturan Menteri Negara Koperasi dan Usaha Kecil dan Menengah Republik Indonesia. Nomor: 06/PER/M.KUKM/V/2016. Tentang Pedoman Penilaian Koperasi. http://www.koperasi.indonesia.com (Akses 08/10/2018)

Rudianto. 2015. Akuntansi Koperasi Edisi Kedua. Jakarta: Erlangga.

Subandi. 2014. Ekonomi Koperasi (Teori dan Praktik). Bandung: Alfabeta.

Sugiyarso, G. 2015. Akuntansi Koperasi. Yogyakarta: CAPS

Undang-Undang Republik Indonesia Nomor 25 Tahun 1992 tentang Perkoperasian. www.depkop.go.id (Akses 08/10/2018) 